\title{
INTENSIVE REARING OF MONO-SEX NILE TILAPIA AND SILVER CARP UNDER MONO-OR POLYCULTURE SYSTEMS AT DIFFERENT STOCKING DENSITIES IN FLOATING NET CAGES
}

Abdelhamid, A. M.

Dept. of Animal Production, Fac. Agric., Mans. Univ., A.R.E.

\begin{abstract}
The experiment of this study was carried out for 6 months on rearing Nile tilapia and silver carp, whether under monoculture or polyculture at different stocking densities. Four floating net cages $(10 \times 10 \times 3 \mathrm{~m})$ were used. The obtained results revealed that the best treatment was the monoculture of all males mono-sex Nile tilapia (10000 fish of $10 \mathrm{-g}$ each/cage) followed by that of polyculture (5000 tilapia of $10-\mathrm{g}$ plus 750 carp of $70-\mathrm{g} /$ cage) concerning their superiority in final bodyweight (235 and 545-g/fish), bodyweight gain (225 and 475-g/fish), average daily bodyweight gain (1.21 and $2.55-\mathrm{g}$ ), specific growth rate (SGR, 1.70 and $1.01 \% /$ day), feed conversion ratio (FCR, 2.41 and 2.45 ), feed cost $/ \mathrm{Kg}$ bodyweight gain (7.78 and 5.89 L.E.), and economic efficiency ( 144.5 and $77.9 \%$, respectively). Moreover, the monoculture of all males mono-sex Nile tilapia was also the best treatment in return (18855 L.E./cage) followed by the polyculture treatment (7500 tilapia of $10 \mathrm{~g}$ with 1100 carp of 70 $\mathrm{g} /$ cage) which gave return of 10868 L.E./cage.

Keywords: Cages - Nile tilapia - Silver carp - Stocking rates - Performance Productivity.
\end{abstract}

\section{INTRODUCTION}

Frankic and Hershner (2003) summarized the benefits of aquaculture in: 1) increase household food supply and improve nutrition, 2) increase household economy through diversification of income and food sources, 3) strengthen marginal economy by increasing employment and reducing food price, 4) improve water resource and nutrient management at household or community levels, 5) preserve aquatic biodiversity through restocking and recovering of protected species, 6) reduce pressure on fishery resources if done sustainable, 7) improving/enhancing habitats, 8) stimulates research and technology development, and 9) increase education and environmental awareness. El-Saidy (2005) recommended mono-sex culture of male Nile tilapia for its better growth performance and economics. Abou Zied and Hassouna (2006) concluded that growth performance of sex reversed Nile tilapia tended to decrease as its stocking rate increased, but feed conversion rate showed contra results. Abo-El-Wafa (1996) stated that tilapia cage culture is productive $\left(\sim 28.1 \mathrm{~kg} / \mathrm{m}^{3} / 5\right.$ months) and economically feasible when scientific management, using suitable tilapia species and size stocked early at optimum numbers and fed with suitable diet. Moreover, Coulibaly et al. (2007) mentioned that production potential of African catfish (Heterobranchus longifilis) from floating cages could be increased by the improvement of rearing conditions (feeding systems, culture management) as 
noted in other species. The aim of the present work was to estimate the benefits of fish (Nile tilapia and silver carp) culture whether under mono-or polyculture systems, particularly at two stocking rates in floating net cages.

\section{MATERIALS AND METHODS}

This study was carried out at Al-Manzalah lake (Raswah Lisa AlGamaliah) using four floating net cages $\left(10 \times 10 \times 3 \mathrm{~m}\right.$ each) for six months $\left(1^{\text {st }}\right.$ May till $30^{\text {th }}$ October 2010). All fish groups were fed on the same diet that contains $25 \%$ crude protein (from Al-Schorok Feed Mill, Al-Matariah, Dakahliah governorate) and offered twice daily (at 8.30 a.m. and 15.00 p.m.) at $3 \%$ of body weight mass daily. All fish species (all male mono-sex Nile tilapia, Oreochromis niloticus, Linn. and silver carp, Hypophalmichthys malitrix, Val.) were purchased from Hatchery and Fish Farm of Yosef Asal at the same district (Raswah Lisa Al-Gamaliah). The following schema illustrates the rearing system:

\begin{tabular}{|c|c|c|c|c|}
\hline Item & $1^{\text {st }}$ Treatment & $2^{\text {nd }}$ Treatment & $3^{\mathrm{rd}}$ Treatment & $4^{\text {th }}$ Treatment \\
\hline Fish species & $\begin{array}{l}\text { All male mono-sex } \\
\text { Nile tilapia }\end{array}$ & Silver carp & $\begin{array}{l}\text { All male mono-sex } \\
\text { Nile tilapia + Silver } \\
\text { carp }\end{array}$ & $\begin{array}{l}\text { All male mono-sex } \\
\text { Nile tilapia + Silver } \\
\text { carp }\end{array}$ \\
\hline Fish weight, $\mathrm{g}$ & 10 & 70 & $10+70$ & $10+70$ \\
\hline $\begin{array}{l}\text { Stocking rate: } \\
\text { Fish/cage } \\
\text { Fish } / \mathrm{m}^{3} \\
\text { Gram } \mathrm{fish} / \mathrm{m}^{3}\end{array}$ & \begin{tabular}{|l}
10000 \\
33.3 \\
333.3 \\
\end{tabular} & $\begin{array}{l}1500 \\
5 \\
350 \\
\end{array}$ & \begin{tabular}{|l}
$5000+750$ \\
19.2 \\
341.7 \\
\end{tabular} & $\begin{array}{l}7500+1100 \\
28.7 \\
506.7\end{array}$ \\
\hline Rearing system & Mono-culture & Mono-culture & $\begin{array}{l}\text { Poly-culture, low } \\
\text { stocking rate }\end{array}$ & $\begin{array}{l}\text { Poly-culture, high } \\
\text { stocking rate }\end{array}$ \\
\hline
\end{tabular}

Biweekly measurements for 30 fish of each species within each cage were recorded concerning body weight, length, and depth in $\mathrm{g}$ and $\mathrm{cm}$, respectively for calculating the condition factor $\left(K=W / L^{3}\right.$, where $W$ and $L$ are body weight and length in $\mathrm{g}$ and $\mathrm{cm}$, respectively), bodyweight gain (BWG), average daily bodyweight gain (DBWG), specific growth rate \{SGR=100 (In. $\left.W_{2}-\ln . W_{1}\right) /$ days $\}$, gain of body length (BLG) and depth (BDG), average daily body length gain (DBLG), and average daily body depth gain (DBDG). Accumulative feed consumption per cage was calculated for feed conversion estimation. Also, water parameters (temperature, $\mathrm{pH}$, and dissolved oxygen) were estimated morning and after noon, every 3 days for each cage (according to Abdelhamid, 1996). Water temperature as degree centigrade was recorded using a thermometer. The $\mathrm{pH}$ value of water was measured using an electric digital $\mathrm{pH}$ meter (Jenway Ltd, model 350-pH meter). Dissolved oxygen concentration was determined using an oxygen meter (model d-5509). Data obtained were statistically analyzed according to Sachs (1976).

\section{RESULTS AND DISCUSSION}

Table (1) presents the ranges, means \pm standard errors, and coefficients of variance (C.V.) of the measured criteria of the fish rearing water quality, i.e. temperature, $\mathrm{pH}$ values, and dissolved oxygen registered 
on the $1^{\text {st }}$ of May till the $31^{\text {st }} 2010$. The after noon values were higher than the morning values for the effect of ambient temperature and consequently for the biotic activities. The C.V. values were small enough because of the homogeneity of the estimated values. These values of water parameters are within the acceptable ranges recommended for pisciculture (Abdelhamid, 1996 and 2009; El-Nady et al., 2001; Abdelhakim et al., 2002; El-Saidy, 2004 and Hassan et al., 2006).

Table (1): Data of fish rearing water as ranges during May - October 2010 at Al-Manzalah lake (Raswah Lisa Al-Gamaliah).

\begin{tabular}{|l|c|c|c|c|c|c|}
\hline \multirow{2}{*}{ Item } & \multicolumn{2}{|c|}{ Temperature, C } & \multicolumn{2}{c|}{ The pH value } & \multicolumn{2}{c|}{ Dissolved oxygen, mg/l } \\
\cline { 2 - 7 } & Morning & After noon & Morning & $\begin{array}{c}\text { After } \\
\text { noon }\end{array}$ & Morning & After noon \\
\hline No. of estimations & 63 & 63 & 63 & 63 & 63 & 63 \\
\hline Range & $23.2-26.9$ & $24.2-28.0$ & $6.20-7.97$ & $7.20-8.10$ & $5.08-7.41$ & $7.55-8.90$ \\
\hline Mean \pm SE & $25.5 \pm 0.15$ & $26.8 \pm 0.16$ & $6.90 \pm 0.05$ & $7.72 \pm 0.04$ & $6.99 \pm 0.05$ & $8.22 \pm 0.07$ \\
\hline C. V. \% & 3.62 & 4.61 & 5.86 & 3.61 & 5.44 & 3.97 \\
\hline
\end{tabular}

C.V. ( coefficient of variance) = S x $100 /$ mean, where S = standard deviation

Table (2) illustrates all collected data of the experimental fish concerning total gains in body weight, length, depth, and condition factor of tilapia [under monoculture (Fig. 1) and polyculture systems at low and high stocking densities (Figs. 3A and 4A, respectively)] and silver carp [under monoculture (Fig. 2) and polyculture systems at low and high stocking densities (Figs. 3B and 4B, respectively)]. Also, comparisons between monoculture and polyculture of either of tilapia or silver carp were given in Figs. (5) and (6), respectively. From the data in these Figs. and Table (2), it is clear that the final body weight of the carp was significantly $(P \leq 0.05)$ heavier than that of the tilapia, particularly under the polyculture system at the low stocking density. The same trend was recorded too for final body length, depth, and k-factor as well as for the total bodyweight gain and average daily bodyweight gain, but the total body length and depth and averages of daily body length and depth were higher for tilapia than carp, except for total body length in $\mathrm{T}_{3}$. However, tilapia reflected higher specific growth rates than carp, particularly under monoculture system or polyculture system at the high stocking density.

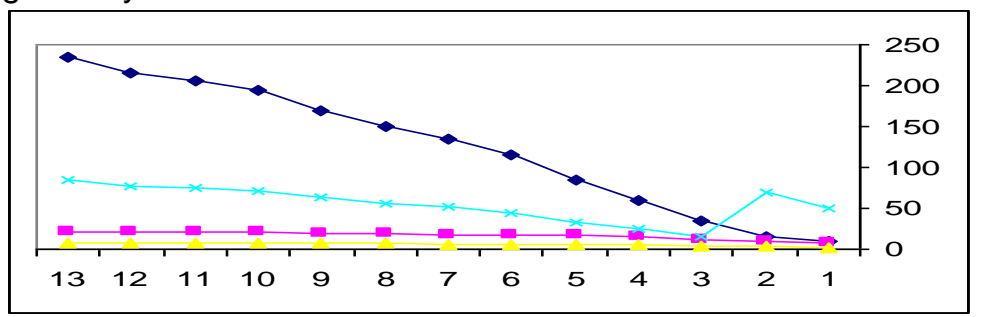

Fig. (1): Body weight (g), condition factor (k), body length $(\mathrm{cm})$, and body depth $(\mathrm{cm})$ curves in descending order (from the upper curve) of the treatment 1 (tilapia, monoculture) throughout the 13-weeks experimental period. 
Abdelhamid, A. M.

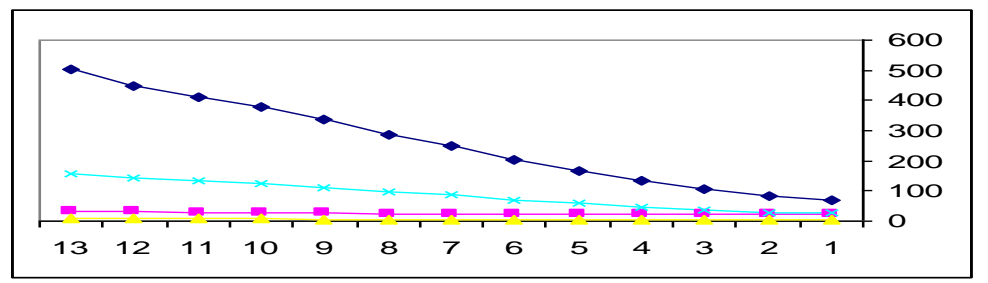

Fig. (2): Body weight (g), condition factor (k), body length (cm), and body depth $(\mathrm{cm})$ in descending order (from the upper curve) of the treatment 2 (silver carp, monoculture) throughout the 13weeks experimental period.

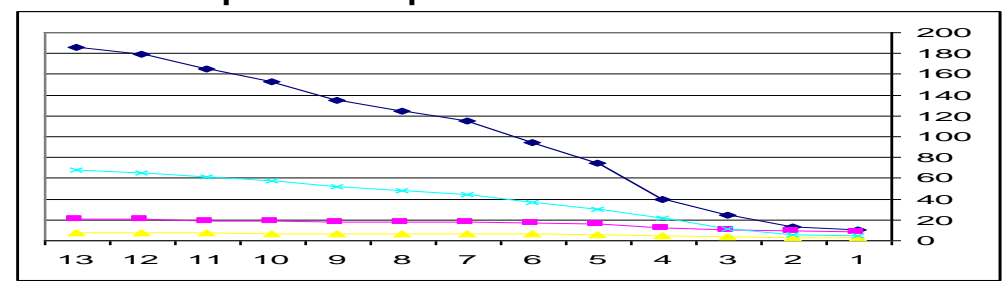

Fig. (3A): Body weight (g), condition factor (k), body length (cm), and body depth $(\mathrm{cm})$ in descending order (from the upper curve) of the treatment 3 (tilapia, polyculture- low density) throughout the 13-weeks experimental period.

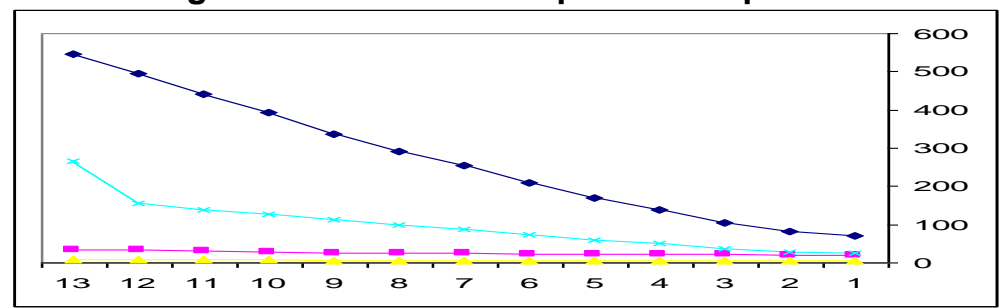

Fig. (3B): Body weight (g), condition factor (k), body length $(\mathrm{cm})$, and body depth $(\mathrm{cm})$ in descending order (from the upper curve) of the treatment 3 (silver carp, polyculture- low density) throughout the 13-weeks experimental period.

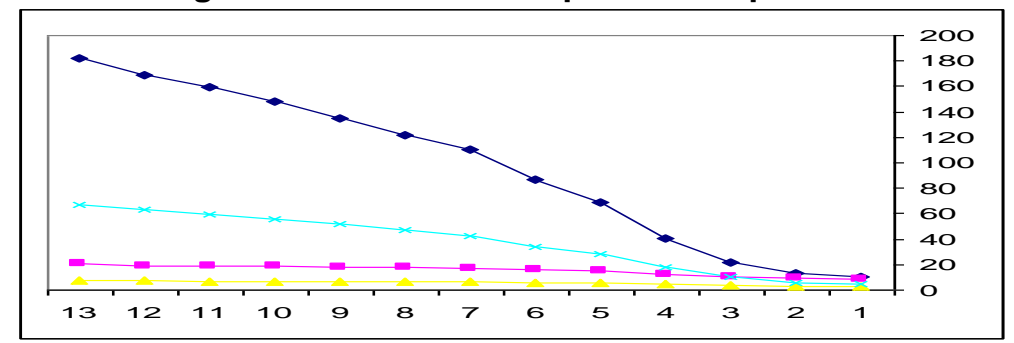

Fig. (4A): Body weight (g), condition factor (k), body length (cm), and body depth $(\mathrm{cm})$ in descending order (from the upper curve) of the treatment 4 (tilapia, polyculture- high density) throughout the 13-weeks experimental period. 


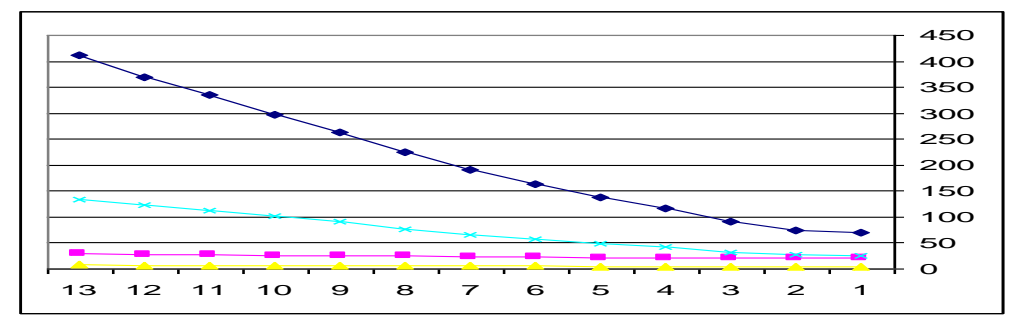

Fig. (4B): Body weight (g), condition factor (k), body length (cm), and body depth $(\mathrm{cm})$ in descending order (from the upper curve) of the treatment 4 (silver carp, polyculture- high density) throughout the 13-weeks experimental period.

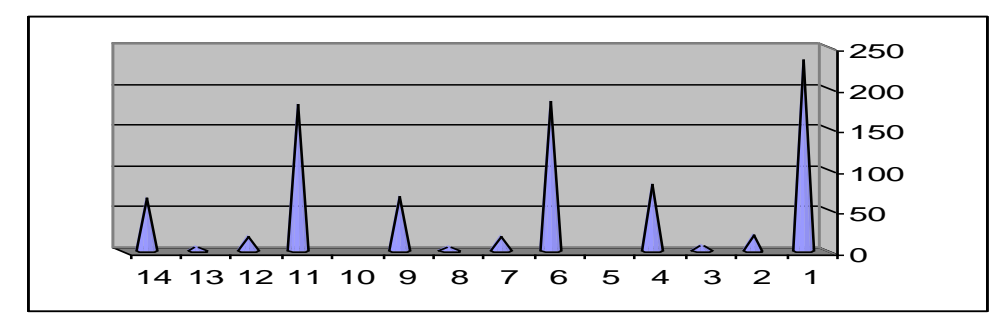

Fig. (5): Comparison between final body measurements (BW, BL, BD, and K-factor) of tilapia under mono (1-4) and polyculture at low (6-9) and high (11-14) stocking densities.

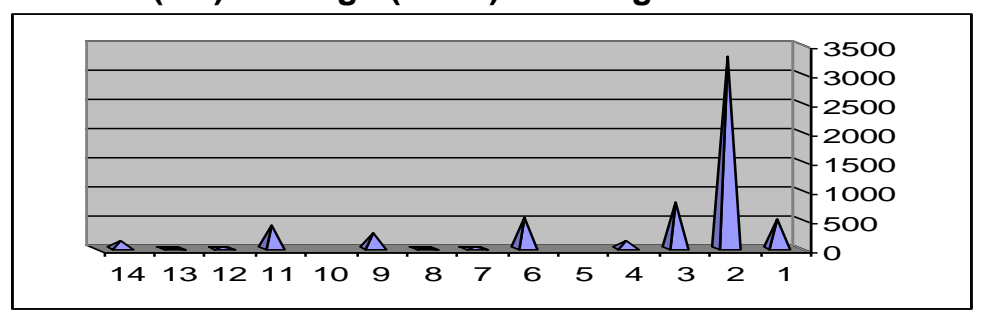

Fig. (6): Comparison between final body measurements (BW, BL, BD, and K-factor) of silver carp under mono (1-4) and polyculture at low (6-9) and high (11-14) stocking densities.

Table (3) presents also a comparison among all the experimental fish groups concerning the catch/ feddan, feed consumption, and feed conversion ratio. The total catch per cage, $\mathrm{m}^{3}$, or feddan was higher for tilapia than for carp for the higher number at stocking as well as for the higher SGR of tilapia than carp. This may be due to that, tilapia consumed more feed than carp, but convert it to growth more efficient than carp, except at $T_{3}$ (polyculture, low stocking rate). Table (3) shows also the feed consumption (consequently feed cost) and weight gain per cage which were also higher for tilapia than silver carp, particularly under monoculture than under polyculture, for the same reasons mentioned before (stocking density and growth rate). Feed conversion was the best (2.41) for tilapia monoculture, but was worst (2.66) for silver carp under polyculture at high stocking density (assuming that 
Abdelhamid, A. M.

both fish species consumed the offered feed at the same feeding rate). The total feed costs and returns per cage were the highest for $T_{1}$ followed by $T_{4}$, $T_{3}$ and at least for $T_{2}$. The feed cost $/ \mathrm{kg}$ gain was at best for $T_{1}$ (tilapia, monoculture), followed by silver carp at $T_{3}$, tilapia at $T_{4}$, tilapia at $T_{3}$, silver carp at $T_{2}$, and silver carp at $T_{4}$. The return and economic efficiency for tilapia were better than for carp, particularly for monoculture than in polyculture. The return and economic efficiency for both species under polyculture were better also at high density than at low density.

Table (2): Summary of the growth performance parameters of intensive fish culture in floating net cages under different rearing systems (mono-and polyculture at different stocking rates).

\begin{tabular}{|c|c|c|c|c|c|c|}
\hline Criteria & $\mathrm{T}_{1}$ (mono) & $\mathrm{T}_{2}$ (mono) & $\mathrm{T}_{3}$ (poly, & ow density) & ${ }_{4}$ (poly, I & igh density) \\
\hline & Tilapia & Silver carp & Tilapia & Silver carp & Tilapia & Silver carp \\
\hline IBW, g & 10 & 70 & 10 & 70 & 10 & 70 \\
\hline IBL, cm & 8.4 & 20.8 & 8.4 & 20.8 & 8.4 & 20.8 \\
\hline IBD, cm & 2.8 & 4.6 & 2.8 & 4.6 & 2.8 & 4.6 \\
\hline IK- factor & 4.92 & 25.45 & 4.92 & 25.45 & 4.92 & 25.45 \\
\hline FBW, g & $235^{b}$ & $505^{a}$ & $186^{c}$ & $545^{\mathrm{a}}$ & $182^{c}$ & $412^{a}$ \\
\hline SGR,\%/d & $1.68^{\mathrm{a}}$ & $1.06^{b}$ & $1.57^{\mathrm{a}}$ & $1.10^{\mathrm{b}}$ & $1.56^{\mathrm{a}}$ & $0.95^{b}$ \\
\hline FBL, cm & $21.7^{b}$ & 33.1a & $20.6^{b}$ & $34.0^{a}$ & $20.3^{b}$ & $29.7^{a}$ \\
\hline FBD, cm & $8.0^{\mathrm{b}}$ & $8.8^{a}$ & $7.4^{\mathrm{c}}$ & $9.1^{\mathrm{a}}$ & $7.4^{\mathrm{c}}$ & $8.0^{\mathrm{b}}$ \\
\hline FK-factor & $84.3^{c}$ & $157.3^{b}$ & $67.9^{c}$ & $264.8^{a}$ & $66.7^{c}$ & $133.0^{b}$ \\
\hline BWG, g & $225^{c}$ & $435^{a}$ & $176^{\mathrm{d}}$ & $475^{\mathrm{a}}$ & $172^{d}$ & $342^{b}$ \\
\hline$B L G, c m$ & $13.3^{a}$ & $12.3^{b}$ & $12.2^{b}$ & $13.2^{\mathrm{a}}$ & $11.9^{b}$ & $8.9^{c}$ \\
\hline BDG, cm & $5.2^{\mathrm{a}}$ & $4.2^{b}$ & $4.6^{b}$ & $4.5^{\mathrm{b}}$ & $4.6^{b}$ & $3.4^{\mathrm{c}}$ \\
\hline DBWG, $\mathbf{g}$ & $1.21^{c}$ & $2.34^{\mathrm{a}}$ & $0.95^{c}$ & $2.55^{\mathrm{a}}$ & $0.93^{c}$ & $1.84^{\mathrm{b}}$ \\
\hline DBLG,mm & $0.72^{a}$ & $0.66^{b}$ & $0.66^{b}$ & $0.71^{\mathrm{a}}$ & $0.64^{b}$ & $0.48^{c}$ \\
\hline DBDG,m m & $0.28^{a}$ & $0.23^{b}$ & $0.25^{\mathrm{b}}$ & $0.24^{\mathrm{b}}$ & $0.25^{\mathrm{b}}$ & $0.18^{c}$ \\
\hline
\end{tabular}

a - d: Means in the same row superscripted with different letters are significantly $(P \leq 0.05)$ different.

IBW (initial body weight), IBL (initial body length), IBD (initial body depth), IK- factor (initial condition factor), FBW (final BW), FBL (final BL), FBD (final BD), FK-factor (final Kfactor), BWG (bodyweight gain), BLG (body length gain), BDG (body depth gain), DBWG (average daily BWG), DBLG (average daily BLG), and DBDG (average daily BDG).

Nour et al. (1993) registered that growth performance, fish net production and feed utilization of grey mullet was decreased with increasing the stocking density. Moreover, Sweilum (1995) found that the growth in length and weight of the two rearing fishes (Nile tilapia and silver carp) slightly increased with the decreasing stocking density. Additionally, Khouraiba et al. (1996) concluded that growth performance and feed efficiency of Penaeus japonicus shrimp were significantly decreased with increasing the stocking density. In addition, Teichert-Coddington (1996) came to the conclusion that total production increased curvilinear but feed conversion ratios, total nitrogen and chlorophyll $\alpha$ decreased linearly as the rate of stocking tilapia increased. He found also that tilapia mean weight decreased curvilinear and tambaqui (Colossoma macropomum) mean weight increased linearly as the rate of stocking tilapia increased. Also, Huang and Chin (1997) mentioned that the size, size variation, percentage survival and production of tilapia fry were found to be significantly affected by stocking density, but not for condition factor. Moreover, Sweilum (1998-a) reported 
that growth and production of $O$. niloticus are related to stocking density, since they increase at low density. El-Sherif (2001) also found improvements in weight and length of the prawn larvae at lower stocking density.

Table (3): Data of fish production and economic efficiency of intensive fish culture in floating net cages under different rearing systems (mono-and polyculture at different stocking rates).

\begin{tabular}{|c|c|c|c|c|c|c|}
\hline \multirow[t]{2}{*}{ Criteria } & \multirow{2}{*}{\begin{tabular}{|c|}
$T_{1}($ mono) \\
Tilapia
\end{tabular}} & \multirow{2}{*}{\begin{tabular}{|c|}
$\mathbf{T}_{2}$ (mono) \\
$\begin{array}{c}\text { Silver } \\
\text { carp }\end{array}$ \\
\end{tabular}} & \multicolumn{2}{|c|}{$\begin{array}{c}\mathrm{T}_{3} \text { (poly, low } \\
\text { density) }\end{array}$} & \multicolumn{2}{|c|}{$\begin{array}{l}\mathrm{T}_{4} \text { (poly, high } \\
\text { density) }\end{array}$} \\
\hline & & & Tilapia & $\begin{array}{l}\text { Silver } \\
\text { carp }\end{array}$ & Tilapia & Silver carp \\
\hline $\begin{array}{l}\text { Catch, kg: } \\
/ \text { cage } \\
/ \mathrm{m}^{3} \\
/ \text { feddan }\end{array}$ & $\begin{array}{c}2350 \\
7.83 \\
98700\end{array}$ & $\begin{array}{c}757.5 \\
2.53 \\
31815\end{array}$ & $\begin{array}{c}930 \\
3.10 \\
39060\end{array}$ & $\begin{array}{c}408.8 \\
1.36 \\
17167.5\end{array}$ & $\begin{array}{c}1365 \\
4.55 \\
57330\end{array}$ & $\begin{array}{c}453.2 \\
1.51 \\
19034.4\end{array}$ \\
\hline $\begin{array}{l}\text { Feed } \\
\text { consumptio,kg/cage }\end{array}$ & 5421 & 1677 & 2201.6 & 874.2 & 3174 & 1001.8 \\
\hline \begin{tabular}{|l|} 
Gain, kg/cage \\
FCR
\end{tabular} & $\frac{2250}{2.41}$ & $\begin{array}{l}652.5 \\
2.57\end{array}$ & $\begin{array}{l}880 \\
2.50\end{array}$ & $\begin{array}{l}356.25 \\
2.45\end{array}$ & $\begin{array}{l}1290 \\
2.46\end{array}$ & \begin{tabular}{|l}
376.2 \\
2.66
\end{tabular} \\
\hline $\begin{array}{l}\text { Feed cost, LE: } \\
\text { /cage } \\
\text { /Kg BW gain }\end{array}$ & $\begin{array}{c}13010.4 \\
5.78\end{array}$ & $\begin{array}{l}4024.8 \\
6.17\end{array}$ & $\begin{array}{c}5283.8 \\
6.00\end{array}$ & $\begin{array}{c}2098.1 \\
5.89\end{array}$ & $\begin{array}{c}7617.6 \\
5.91\end{array}$ & $\begin{array}{c}2404.3 \\
6.39\end{array}$ \\
\hline $\begin{array}{l}\text { Return, LE: } \\
\text { /cage } \\
\text { / } \text { m }^{3} \\
\text { /feddan* }\end{array}$ & $\begin{array}{c}18800 \\
62.67 \\
789600\end{array}$ & $\begin{array}{c}2840.6 \\
9.47 \\
119305\end{array}$ & $\begin{array}{c}6324.0 \\
21.08 \\
265608\end{array}$ & $\begin{array}{l}1635.0 \\
5.45 \\
68670\end{array}$ & $\begin{array}{c}9282.0 \\
30.94 \\
389844\end{array}$ & $\begin{array}{c}1586.2 \\
5.29 \\
66620.4\end{array}$ \\
\hline $\begin{array}{l}\text { Economic } \\
\text { efficiency }{ }^{\star \star}(\%)\end{array}$ & 144.5 & 70.58 & 119.7 & 77.9 & 121.8 & 65.97 \\
\hline
\end{tabular}

FCR (Feed conversion ratio), $\quad{ }^{*}$ : Feddan (Egyptian area unit) $=4200 \mathrm{~m}^{2}$ **: Economic efficiency (return x 100/ feed cost), according to the local prices year 2010 for fish and feed, where 1 US dollar $(\$)=5.8051$ Egyptian pound (L.E.).

Also, El-Saidy and Gaber (2002) confirmed that mean final weight and length, weight and length gain, SGR, and feed conversion of $O$. niloticus were significantly $(P \leq 0.01)$ the best at the lower stocking density; while, total production and net production exhibited significantly the opposite trend. Bakeer et al. (2003) revealed too that silver carp cultured in cages gave pronounced $(\mathrm{P} \leq 0.05)$ increases in body weights at lower stocking density. Additionally, Kheir and Saad (2003) proved that the least stocking rate attained the highest significant $(P \leq 0.05)$ final weight, weight gain, SGR, feed conversion, and protein efficiency ratio for O. niloticus. Abdel-Aal et al. (2004) working on $\mathrm{O}$. niloticus, revealed that while individual fish weight and dressing percentage as well as flesh percentage decreased, fish yield and money profit increased with the increase in fish stocking density. However, El-Saidy (2004) revealed no significant differences in average final weight and SGR between stocking rates, but mean biomass at harvesting, total weight gain, daily weight gain and survival rate differ significantly $(P \leq 0.05)$. The best fish growth, production and profitability were achieved from the highest stocking rate. Mullet growth was the best under the low density, but Nile tilapia grow better under the highest density. Additionally, Abou Zied et al. (2005) also revealed that harvesting body weight, total gain, daily gain and SGR of fish were affected by stocking rates, where higher values for tilapia 
Abdelhamid, A. M.

and mullet were obtained at lower densities. Yet, body mass of tilapia at harvesting and the net production per feddan were higher at the highest stocking rate. Since, Abdel-Tawwab et al. ( 2005) concluded that Nile tilapia may quickly adapted to high rearing density by enhancing feed quality especially protein level in the diet to prevent the deleterious effect in fish farm. Recently, Bakeer et al. (2006) concluded also that stocking density released significant effects on final body weight and survival in favor of lower stocking density. Hassan et al. (2006) noticed also that increasing the stocking density decreased significantly body weight and length of tilapia aurea. Yet, Bakeer et al. (2007) recommended the medium stocking density [12 O. niloticus fish (50 g initial weight) $/ \mathrm{m}^{3}$ ] to get the optimum marketable fish size at harvest under monoculture semi-intensive system. Lastly, Alam (2009) concluded that the highest stocking density [150 fish (2.8 g initial weight $/ \mathrm{m}^{3}$ ] of monosex male Nile tilapia reared in concrete tanks exhibited the highest production and net profit.

Gonzales-Corre (1988) used mono- and polyculture at different stocking densities and found that a competition was evident between $P$. monodon and $O$. niloticus at a stocking combination of 6,000 P. monodon /hectar plus 6,000 O. niloticus / hectar. Total yield from polyculture was better than monoculture. Polyculture of $P$. monodon at $6,000 /$ ha and $O$. niloticus at 4,000/ha appeared feasible. However, Khouraiba et al. (1991) showed that common carp can be cultured with Nile tilapia in cages without affecting the growth and net production of Nile tilapia at ratios of 1:10 and 2:10 for tilapia and carp, respectively, $21: 10$ is the optimum ratio. They added that polyculture system gave higher $(30 \%)$ total net production than that of tilapia alone in a monoculture. On the other hand, Brummett and Alon (1994) concluded that tilapia growth, reproduction and food conversion were adversely affected by the presence of crayfish $(P \leq 0.01)$. Sweilum (1998-b) noticed also that the silver carp was the best species in tilapia rearing ponds, with it the weight gain of $O$. niloticus reached its maximum value. The specific growth rate was 1.91 for Nile tilapia reared with silver carp, 1.56 with common carp, 1.43 with the two species of carp and 1.24 for the Nile tilapia reared alone in the pond. On the other hand, the total production of $O$. niloticus was $1.806 \mathrm{Kg}$ in the pond contained silver carp and $1.479 \mathrm{~kg}$ in pond contained common carp. This is a result of the observation that the optimum value of feed conversion (2.65) occurred for tilapia reared with silver carp. However, Abdelhakim et al. (2001) concluded that tilapia, mullet and eel can be cultured together in earthen ponds. Sweilum (2001) obtained better growth rate and production for $\mathrm{O}$. niloticus in polyculture combination (Nile tilapia, Sarotherodon galilaeus and Clarias gariepinus) than in duoculture and monoculture systems. He added that $O$. niloticus showed better growth rate when cultured with $C$. gariepinus than with $S$. galilaeus. Yet, Kheir et al. (2002) reported no significant difference for growth performance among fish or prawn alone or in polyculture. Such a result may indicate that the growth of both species was not affected by the presence of the other. The feed conversion ratio was lower in polyculture than in the monoculture indicating that the polyculture species consumed less feed and utilized the feed more efficiently than the monoculture ones. Additionally, Saad and Habashy (2002) 
cultured the exotic crayfish (Procambarus clarkia, Girard, 1852) with common carp (Cyprinus carpio, Linnaeus, 1758); silver carp (Hypophthalmichthys molitrix, Valenciennes, 1844); Nile tilapia (Oreochromis niloticus, Linnaeus, 1757); and Sartherodon galilaeus (Artedi, 1757). There were no significant differences in the survival rate of the four fish species cultured in combination with the crayfish and the fish kept alone. Also, there were no significant differences in weight gain and specific growth rate. However, El-Saidy (2004) concluded that the semi-intensive polyculture of mullet and Nile tilapia is advised to increasing fish production and overcome the problems of land and water shortage. Also, Kheir and Saad (2004) found that the stocking rate of $4: 1 \quad$ O. niloticus : C. gariepinus produced higher growth, better FCR and higher production of marketable tilapia and catfish, indicating the absence of interspecies competition. So, it may be concluded that $4: 1 \quad$ O. niloticus : C. gariepinus stocking ratio is sufficient for effective recruitment control of tilapia and achieving higher growth and production of the two species. However, Kheir et al. (2004) recommended that rearing of males and females separately is necessary for increasing $O$. niloticus fingerlings growth and production in fish cage farms. De Silva et al. (2008) concluded that the introduction of of Jundia Rhamdia quelen (Quoy \& Gaimard) and Nile tilapia to carp in polyculture had a positive effect on all growth parameters when compared with carp only. The reduction in common carp ratio also had a positive effect on all growth and yield parameters. Moreover, Essa et al.(2008) revealed that Nile tilapia and silver carp culture in net-enclosures model was more productive $\left(12.26 \mathrm{~kg} / \mathrm{m}^{3} / 5\right.$ months) and economic than monoculture of Nile tilapia model $\left(5.77 \mathrm{~kg} / \mathrm{m}^{3} / 5\right.$ months).

\section{CONCLUSION}

From the obtained results, it could be concluded and recommended that the best treatment is the monoculture of all males monosex Nile tilapia followed by that of polyculture for their superiority in final bodyweight, bodyweight gain, average daily bodyweight gain, specific growth rate, feed conversion, feed cost/Kg bodyweight gain, economic efficiency, and return.

\section{REFERENCES}

Abdel-Aal, M. M.; Hassan, A. A. and Mahmoud, A. A. (2004). Effect of stocking density on growth performance and body composition of Nile tilapia (Oreochromis niloticus) in rice fields. Proc. The $1^{\text {st }}$ Inter. Conf. Vet. Res. Div., Nrc, Cairo, Egypt, Feb. 15-16 ${ }^{\text {th }}$, pp: 384-392.

Abdelhakim, N.F., Baker, M.N. and Soltan, M.A. (2001). Effect of dietary protein levels on growth performance and pond productivity of Nile tilapia (Oreochromis niloticus), eel (Anguilia anguilia) and grey mullet (Mugil cephalus) reared in polyculture system. Egypt. J. Aquat. Biol. \& Fish., 5 (4): 61-85. 
Abdelhakim, N.F., Baker, M.N. and Soltan, M.A. (2002). Aquatic Environment for Fish culture. Cairo, (ISBN: $977-298-228-5)$.

Abdelhamid, A.M. (1996). Field and Laboratorial Analysis in Animal Production. Dar Annashr for Universities, Cairo, I.S.B.N. 977-552647-7, $680 \mathrm{p}$.

Abdelhamid, A.M. (2009). Modern Approach in Aquaculture. New Universal Office, Alexandria, I.S.B.N. 977-438-053-3, 393 p.

Abdel-Tawwab, M.; Mousa, M. A. A., Sharaf, S. M. and Ahmad, M. H. (2005). Effect of crowding stress on some physiological functions of Nile tilapia, Oreochromis niloticus (L.) at different dietary protein levels. International Journal of Zoological Research, 1 (1): 41-47.

Abo-El-Wafa, M. A. (1996). An experiment for scientific management of fish cage culture in Dakahlia and Damietta governorates. Menofiya $\mathrm{J}$. Agric. Res., 21 (3): 783-794.

Abou Zied, R. M. and Hassouna, M. M. E. (2006). Evaluation of net enclosures systems on sex reversed Nile tilapia, Oreochromis niloticus, fry production at a commercial hatchery in Fayoum governorate. Fayoum J. Agric. Res. \& Dev., 20 (1): 162- 171.

Abou Zied, R. M.; Abd El-Maksoud, A. M. S. and Ali, A. A. A. (2005). Effect of stocking rates of Nile tilapia (Oreochromis niloticus L.) and grey mullet (Mugil cephalus L.) on their performance in polyculture earthen ponds. Annals of Agric. Sc., Moshtohor, 43 (3): 1057-1066.

Alam, A. A. E. (2009). Effect of feeding frequency and stocking density on the performance of mono-sex Nile tilapia in concrete ponds. M. Sc. Thesis, Fac. of Agric., Minufiya Univ.

Bakeer, M. N.; Abdel-Gawad, A. S., Abdel-Rahman, S. and Nossier, M. I. (2003). Biological and economical investigations of silver carp (Hypophthalmichthys molitrix) cultured in cages at different stocking densities and manuring treatments. Intern. Conf. "Fish Wealth and Food Security in Arabic and Islamic Countries", 22-24 Oct., Al-Azhar Univ., 19p.

Bakeer, M. N.; Mahmoud, A. A., Radwan, M. I. and Hassan, A. A. (2006). Growth performance and survival of Nile tilapia deeds (Oreochromis niloticus) reared in concrete tanks during winter season under different stocking densities. J. Agric. Sci. Mansoura Univ., 31 (5): 2719-2731.

Bakeer, M. N.; Mostafa, M. A. A. and Higaze, A. Z. (2007). Effect of fish size and density at initial stocking on growth performance and fish marketable size. J. Agric. Sci. Mansoura Univ., 32 (3): 1803-1813.

Brummett, R. E. and Alon, N. C. (1994). Polyculture of Nile tilapia (Oreochromis niloticus) and Australian red claw crayfish (Cherax quadricarinatus) in earthen ponds. Aquaculture, 122: 47-54.

Coulibaly, A.; Ouattara, I. N. Koné, T. N'Douba, V. Snoeks, J. Gooré Bi, G. and Kouamélan, E. P. (2007). First results of floating cage culture of the African catfish Heterobranchus longifilis Valenciennes, 1840: Effect of stocking density on survival and growth rates. Aquaculture, 263:61-

67. 
De Silva, L. B.; Barcellos, L. J. G., Quevedo, R. M., De Souza, S. M. G., Kessler, A. D., Kreutz, L. C., Ritter, F., Finco, J. A. And Bedin, A. C. (2008). Introduction of Jundia Rhamdia quelen (Quoy \& Gaimard) and Nile tilapia Oreochromis niloticus (Linnaeus) increases the productivity of carp polyculture in southern Brazil. Aquaculture Research, 39: 542551.

El-Nady, M. A.; Kamar, M. G., Hafez, F. A. And Abu-Seif, R. A. (2001). Effect of different husbandry methods on water quality and growth of some freshwater fishes. Egypt. J. Aquat. Biol. \& Fish., 5 (4): 295-318.

El-Saidy, D. M. S. D. (2004). Growth, production and economic profitability of Nile tilapia and mullets in semi-intensive polyculture systems under Egyptian fish farm conditions. Proc. The $1^{\text {st }}$ Inter. Conf. on the Exportable Trends for Egyptian Fish. May 11-12, Ain Shams Univ.,Cairo,pp:156-169.

El-Saidy, D. M. S. D. (2005). Growth performance and feed utilization of mono-sex (male or female) and normal mixed sex Nile tilapia, Oreochromis niloticus (L.) cultured in tanks. Minufiy J.Agric. Res., 30 (3):877-889.

El-Saidy, D. M. S. D. and Gaber, M. M. A. (2002). Intensive culture of Nile tilapia, Oreochromis niloticus in concrete tanks in Egypt: Effect of stocking density and feeding levels on growth performance, production traits, feed conversion and body composition. Proc. $1^{\text {st }}$ Sci. Conf. Aqu., El-Arish,13-15Dec.pp:1-22.

El-Sherif, M. S. (2001). Studies on growth performance of prawn (Macrobrachium rosenbergii) as affected with type of feeding and stocking density. J. Agric. Sci. Mansoura Univ., 26 (7): 4177-4185.

Essa, M. A.; Goda, A. M. A. S., Hanafy, M. A., El-Shebly, A. A., Mohamed, R. A. and El-Ebiary, E. H. (2008). Small-scale fish culture: guiding models of aquaponics and net-enclosures fish farming in Egypt. Egyptian Journal of Aquatic Research, 34 (3): 320-337.

Frankic, A. and Hershner, C. (2003). Sustainable aquaculture: developing the promise of aquaculture. Aquaculture International, 11: 517-530.

Gonzales-Corre, K. (1988). Polyculture of tiger shrimp (Penaeus monodon) with Nile tilapia (Oreochromis niloticus) in brackishwater fishponds. Proc. The $2^{\text {nd }}$ Inter. Symp. on Tilapia in Aquaculture. ICLARM Conf. Proc., pp:15-20.

Hassan, A. S.; Hassan, A. A. and Mahmoud, S. H. (2006). Effect of stocking rate and organic fertilization on the growth performance of tilapia aurea (Oreochromis aureus). J. Agric. Sci. Mansoura Univ., 31 (2): 617-625.

Huang, W. B. and Chin, T. S. (1997). Effect of stocking density on survival, growth, size variation, and production of tilapia fry. Aquaculture Research, 28: 165-173.

Kheir, M. T. and Saad, A. S. (2003). Growth performance and feed utilization of Oreochromis niloticus (Linnaeus, 1757) fingerlings as affected with stocking density and feeding regime. J. Egypt. Acad. Soc. Environ. Develop., (B-Aquaculture), 4 (2): 1-21. 
Kheir, M. T. and Saad, A. S. (2004). Recruitment control of Oreochromis niloticus (Linnaeus, 1757) with Clarias gariepinus (Burchell, 1822) in a polyculture system. J. Egypt. Ger. Soc. Zool., 45B: Vertebrate Anatomy \& Emberyology, 53-65.

Kheir, M. T.; Habashy, M. M. and Saad, A. S. (2002). Observations on growth and survival of silver carp Hypophthalmichthys molitrix and juveniles of freshwater prawn Macrobrachium rosenbergh in monoculture and polyculture systems. J. Egypt. Acad. Soc. Environ. Develop., (B-Aquaculture) 2 (1): 17-27.

Kheir, M. T.; Mechaeil, M. M. and Saad, A. S. (2004). Rearing of males and females Oreochromis niloticus $\mathrm{L}$. fingerlings separately and mixed in floating cages. J. Egypt. Acad. Soc. Environ. Develop., (BAquaculture),5(1):55-66.

Khouraiba, H. M.; El-Sherif, M. S. and Al-Farsi, E. M. (1996). Effect of stocking density and dietary protein level on growth performance and feed utilization of shrimp, Penaeus japonicus juvenile, in nursery system. Egypt. J. Appl. Sci., 11 (11): 262-284.

Khouraiba, H. M.; El-Sherif, M. S. and Dansoury, M. A. K. (1991). Enhanced fish production through polyculture system of Nile tilapia (Tilapia nilotica) with common carp (Cyprinus carpio) in floating cages. Zagazig Vet. J., 19 (4): 854-864.

Nour, A.; Mabrouk, H., Omar, E., Abo El Wafa, M. And Abou Akkada, A. (1993). Effect of feeding levels and stocking densities on growth performance and feed utilization of grey mullet (Mugil cephalus). Proceedings of Aquaculture Symposium "Technology and Investment Opportunities", 11-14 April, Riyadh, Saudi Arabia, pp: 550559.

Saad, A. S. and Habashy, M. M. (2002). Survival and growth rates of early stages of some fish species reared with the freshwater crayfish, Procambarus clarkii (Girard, 1852). Egypt. J. Aquat. Biol. Fish.,6(3):163-180.

Sachs, L. (1976). Statistische Methoden, Ein Soforthelfer. 3. Neubearbeitete Auflage. Springer - Verlag. Berlin, Heidelberg, New York.

Sweilum, M. A. (1995). Studies on rearing of some available species of carp and tilapia in ponds. Ph.D. Thesis, Faculty of Science, Benha University.

Sweilum, M. A. (1998-a). Observations on growth and production of Oreochromis niloticus reared in floating cages. Bull. Fac. Sci., Zagazig Univ., 20 (1): 224-238.

Sweilum, M. A. (1998-b). Comparison of silver carp and common carp usefulness as additional fish in tilapia rearing ponds. Bull. Fac. Sci., Zagazig Univ., 20 (2): 288-299.

Sweilum, M. A. (2001). Growth performance and production of Oreochromis niloticus using polyculture systems and fertilizers. Egypt. J. Aquat. Biol. \& Fish., 5 (2): 105-119.

Teichert-Coddington, D. R. (1996). Effect of stocking ratio on semi-intensive polyculture of Colossoma macropomum and Oreochromis niloticus in Honduras, Central America. Aquaculture, 143: 291-302. 
الرعاية المكثفة للبلطي النيلي وحيد الجنس والمبروك الفضي بنظامي منفرد ومتعدد

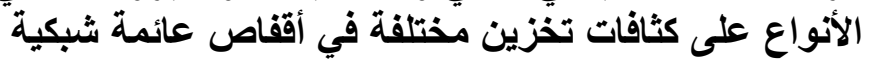
عبد الحميد محمد عبد الحميد قسم إنتاج الحيوان، كلية الزراعة الحمة، جامعة المنصورة، ج.م.ع.

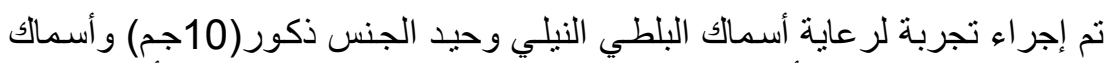

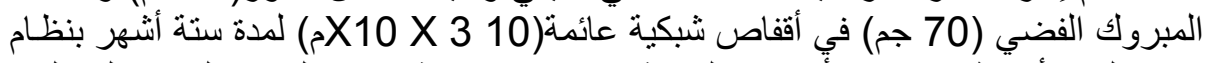

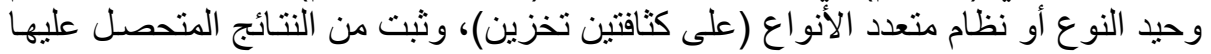

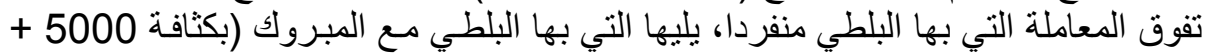

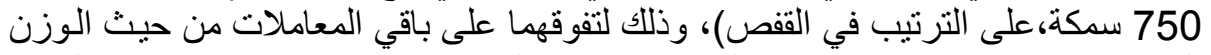
النهائي (235 و 545جم/سمكة)، الزيادة في وزن الجسم (225 و و

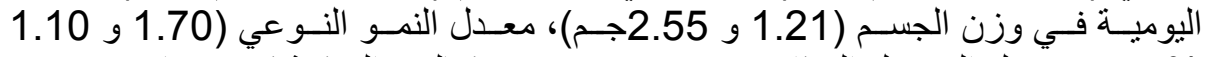

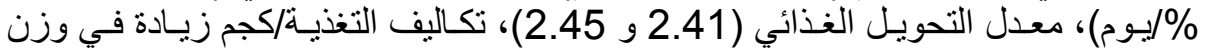

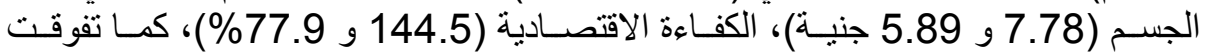

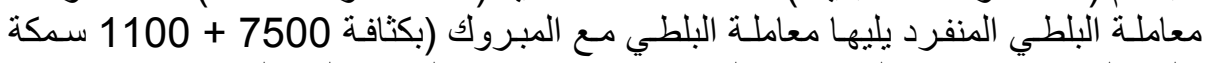

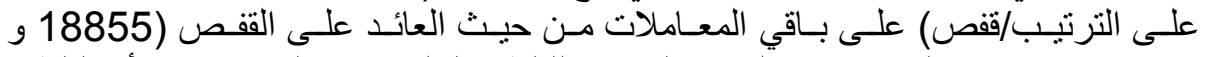

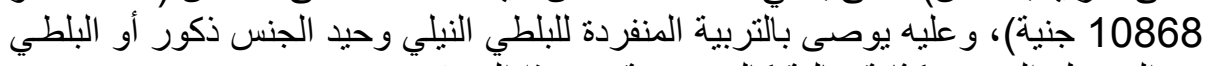
مع المبروك الفضي بكثافة عالية كالمستخدمة في هذا البحثة.

كلية الزراعة - جامعة المنصورة كلية الزراعة - جامعة كفر الثيخ
قام بتحكيم البحث

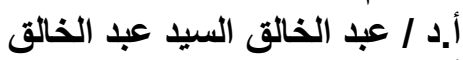
أ.د / أد / عوزى ابراهيم معجوز الديد 